Geliş tarihi / Received: 28.03.2021

Kabul tarihi / Accepted: 18.01.2022

Atıf İçin: Arslan F M, Taşlıca S, Karakurt Ç, Gürlek G, 2022. İnsan Canlı Dokusuna Yerleştirilen Termoelektrik Jeneratörden Elde Edilen Güce Farklı Parametrelerin Etkisi. Iğdır Üniversitesi Fen Bilimleri Enstitüsü Dergisi, 12(1): 378388.

To Cite: Arslan F M, Taşlıca S, Karakurt Ç, Gürlek G, 2022. The Effect of Different Parameters on The Amount of Obtained Power The Thermoelectric Generator Placed in The Human Living Tissue. Journal of the Institute of Science and Technology, 12(1): 378-388.

\title{
The Effect of Different Parameters on the Amount of Obtained Power the Thermoelectric Generator Placed in the Human Living Tissue
}

\author{
Feyzullah Mertkan ARSLAN ${ }^{1}$, Simge TAŞLICA ${ }^{1}$, Çağan KARAKURT ${ }^{1}$, Gökhan GÜRLEK ${ }^{1 *}$
}

\begin{abstract}
Studies on thermoelectric generators (TEG) are becoming widespread day by day and the diversity of usage areas of generators is increasing. Individuals using TEG modules appear to be able to produce the required electricity for various uses from their own bodies. It is hoped that electricity will be generated from TEG modules that will be implanted in the human body because of this foresight. In order to obtain power from these TEG modules, which can be used for implantable devices, the temperature difference in different parts of the body is used. In the study, a thermal model of human living tissue was examined to investigate parameters affecting energy harvesting from human with TEG. A realistic TEG model was determined to accurately calculate the power generated by TEG. The thermal model was applied with using the finite volume method (FVM). Four important factors that affect generated power by TEG were chosen such as fat thickness $\left(L_{f a t}\right)$, leg length of TEG $\left(L_{\text {leg }}\right)$, convection boundary condition on skin $\left(h_{\text {skin }}\right)$ and heat generation of muscle tissue $\left(Q_{\text {gen }}\right)$. The effects of these factors on temperature difference of TEG legs and power output were investigated using $2^{\mathrm{k}}$ factorial design method. As a result, maximum and minimum values were found as $0.26{ }^{\circ} \mathrm{C}$ and $1.13{ }^{\circ} \mathrm{C}$ respectively for the temperature difference between legs. According to these temperature difference values, the power outputs obtained from the TEG module are $3.86 \mu \mathrm{W}$ and $55.54 \mu \mathrm{W}$, respectively. In addition, $L_{\text {leg }}, h_{\text {skin }}$ and $Q_{\text {gen }}$ have a positive effect on TEG power output. As analysis of variance (ANOVA) result, the percentage contribution of factors A and B is high, so they have strong effects on both responses.
\end{abstract}

Keywords: Thermoelectric generator, energy harvesting from human body, thermal model of human tissues

Feyzullah Mertkan ARSLAN (Orcid ID: 0000-0001-8359-7743), Simge TAŞLICA (Orcid ID: 0000-0002-5384-9812), Çağan KARAKURT (Orcid ID: 0000-0003-0907-7509), Gökhan GÜRLEK (Orcid ID: 0000-0001-5324-1818), Ege Üniversitesi, Mühendislik Fakültesi, Makina Mühendisliği Bölümü, İzmir, Türkiye

*Sorumlu Yazar/Corresponding Author: Gökhan Gürlek, e-mail: gokhan.gurlek@ege.edu.tr

Makale, 19-21 Kasım 2020 tarihlerinde Kayseri’de düzenlenen “International Conference on Energy, Environment and Storage of Energy, ICEESEN2020” kapsamında sözlü sunum olarak sunulmuştur. 


\section{INTRODUCTION}

There are several reasons for the growing interest in thermoelectric applications. The emergence of semiconductor materials, which are found to have much higher thermoelectric performance than pure metals, has accelerated the researches. On the other hand, the expectation of producing clean, quiet and low-cost energy has also spread the use of thermoelectric generators (Chakraborty et al., 2006). Looking at the basis of thermoelectric power generation technology, it is seen that a thermoelectric generator consisting of p-type and n-type semiconductors directly transforms the thermal energy created by the temperature difference caused by the hot and cold surfaces of it into electrical energy (Liu et al., 2016). In order to utilise these thermoelectric power generators, which generate electricity from temperature differences according to the Seebeck effect, in energy harvesting applications, research and efficiency-enhancing applications are continuing (Şener et al., 2021).

TEG modules have found very different usage areas especially in recent years. Perhaps the most important of these areas is medical practice. It is aimed to obtain electricity power by using a person's body temperature and to use this power in different areas. The studies conducted to obtain the power required to operate the auxiliary implanted devices in the body or to obtain power for the devices used as accessories come to the fore (Yang et al., 2007).

The most important problem for implantable devices is energy supply. Short-lasting batteries that do not match the life time of the patient are generally used. This means that the patient is going to undergo surgery to insert a new battery. Various studies have been conducted, such as the use of glucose as a fuel in the body to extend battery life. As the most recent studies, thermoelectric systems using body temperature have been found more applicable (Yang et al., 2007). Whether the power generated by thermoelectric generators corresponds to the power consumed by implantable medical devices is one of the biggest question marks. The power consumed by the implanted medical devices actually used is between a few microW and $\mathrm{mW}$. The amount of required power of these devices to operate is given in the Table 1 (Schmidt and Skarstad, 2001).

Table 1. Power requirement for implanted devices to operate (Schmidt and Skarstad, 2001)

\begin{tabular}{lll}
\hline Implanted device & Application subject & Power requirement \\
\hline Cardiac defibrillator & Ventricular tachycardia or fibrillation & $30-100 \mu \mathrm{W}$ \\
Cardiac pacemaker & Conduction disorders & $30-100 \mu \mathrm{W}$ \\
Neurological stimulator & Essential tremor & $30 \mu \mathrm{W}$ to several mW \\
Drug pump & Spasticity & $100 \mu \mathrm{W}$ to $2 \mathrm{~mW}$ \\
Cochlear implants & Help listening & Several $\mu \mathrm{W}$ to $10 \mathrm{~mW}$ \\
\hline
\end{tabular}

A lot of research has been done on the development of suitable thermoelectric generators for the needs. Chen and Wright demonstrated the implantable left ventricular assist device (LVAD) and deep brain neurological stimulator as devices that can be operated with a thermoelectric generator (Chen and Wright, 2012). The tissue close to the skin surface can be modeled as three layers consisting of muscle, fat and epidermis (skin). Previous studies have shown that a 1-5 K temperature gradient is present in adipose tissue (Yang et al., 2007). Studies have shown that the maximum temperature gradients are in the upper back and abdomen during rest. This temperature change is between 1 and $2 \mathrm{~K}$. A maximum temperature gradient of $4.75 \mathrm{~K}$ is observed in the abdominal region in case of exposure to high convective effects during running or in windy areas. As a result of the researches, it has been determined that the temperature differences in the abdominal region are higher in different physical exercises compared to other regions (Yang et al., 2007). In addition to this study, Yuan et al. analyzed the thermal model of human tissue with an implanted thermoelectric generator. They examined the effect of convection on the skin surface and the effects of film coefficient and ambient temperature (Yuan et al., 2018). Power was obtained with thermoelectric generators placed on four body areas, including forehead, wrist, palm and calf, and performances during different activities (resting, walking and running, etc.) were examined. It was observed that the highest power generation occurred during running 
activity and in the forehead region and was $9.5 \mathrm{~mW}$. In case the body temperature was above $35{ }^{\circ} \mathrm{C}$, at least $5 \mathrm{~mW}$ of power was obtained with thermoelectric generators (Rosli and Mohamed, 2018).

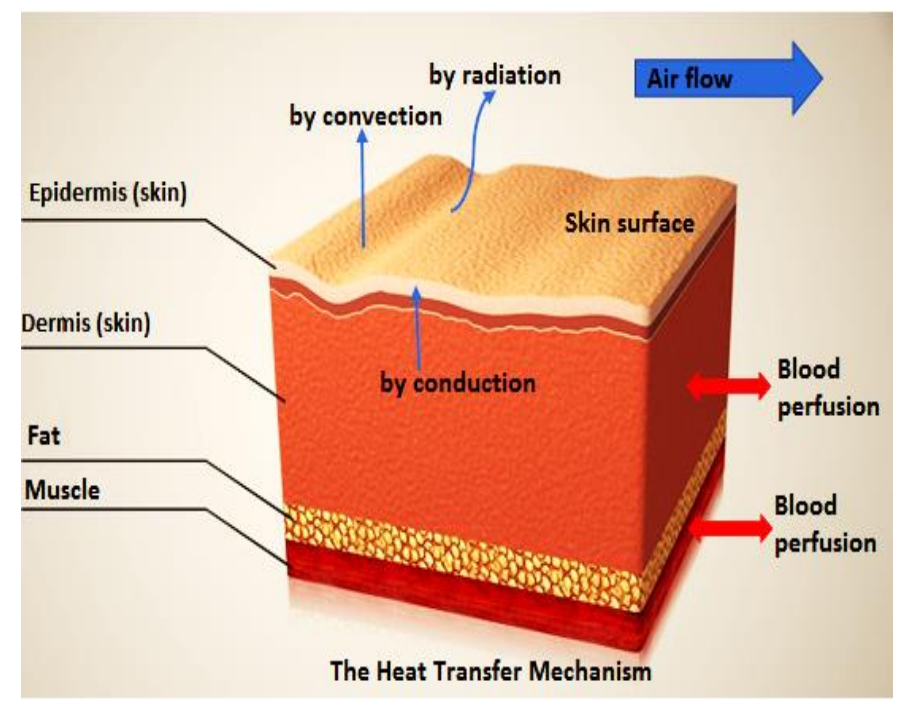

Figure 1. The heat transfer mechanism in human living tissue.

When the studies on the subject are investigated, in this study, the parameters affecting the power to be obtained from the human body with the TEG module were examined and the thermal model of human living tissue was created. While creating the thermal model, the heat transfer mechanism in human living tissue shown in Figure 1 was used. In order for the thermal model to work correctly and to calculate the power obtained from the module exactly, a realistic TEG model is used. Four essential factors determining the power produced by TEG $\left(\mathrm{L}_{\text {leg }}, \mathrm{L}_{\text {fat }}, \mathrm{h}_{\text {skin, }}\right.$, and $\mathrm{Q}_{\mathrm{gen}}$ ) were chosen for this purpose. The effects of these factors on power output were analysed using a statistical method. Two levels in the appropriate range were determined for these 4 factors. Thus, contribution rates on response (power output of TEG) and interactions of factors can be analysed properly. Open source RStudio software was used for all statistical calculations.

The original side of the study is to perform the thermal analysis of the thermoelectric module implanted inside the human body and to determine how the four essential factors affect the results with the statistical analysis method.

\section{MATERIALS AND METHODS}

\section{Numerical Model}

\section{Tissue model}

In the study, 3D heat transfer model of living tissues is established. To model the heat transfer of human tissues, a rectangular prism shaped area was chosen (35mm width $\mathrm{x} 35 \mathrm{~mm}$ depth). Geometric and thermophysical properties of muscle, fat and skin are shown in Table 2. In order to investigate the effect of fat tissue thickness on TEG power output, fat thicknesses of the model are selected $12 \mathrm{~mm}$ and 30 mm (Ishida et al., 1992; Hoffmann et al., 1994; C. D. Yuan et al., 2018).

Table 2. Geometric and thermophysical properties of tissues *(Ishida et al., 1992) **(Hoffmann et al,1994) ***(C. D. Yuan et al., 2018)

\begin{tabular}{|c|c|c|c|}
\hline Properties & Fat & Muscle & Skin \\
\hline Thickness (mm) & $12-30 *$ & $15 *$ & $1.57 * *$ \\
\hline Density $\left(\mathrm{kg} \mathrm{m}^{-3}\right) * * *$ & 911 & 1090.4 & 1109 \\
\hline Heat capacity $\left(\mathrm{j} \mathrm{kg}^{-1} \mathrm{~K}^{-1}\right) * * *$ & 2348.3 & 3421.2 & 3390.5 \\
\hline Thermal conductivity $\left(\mathrm{W} \mathrm{m} \mathrm{m}^{-1} \mathrm{~K}^{-1}\right) * * *$ & 0.21 & 0.49 & 0.37 \\
\hline
\end{tabular}


Significant change in temperature gradient is seen in the fat layer close to the skin. The temperature gradient in the fat layer is primarily a function of blood perfusion rate, near-skin convective heat transfer coefficient, and skin temperature. The heat transfer mechanism within the tissue near the skin surface can be calculated using a 1-dimensional tissue model based on the Pennes Bio-heat equation (Chen and Wright, 2012),

$$
\rho_{t} c_{t} \frac{\partial T_{t}}{\partial t}=\nabla\left(k_{t} \nabla T_{t}\right)+q_{m e t}^{\prime \prime \prime}+\omega \rho_{b} c_{b}\left(T_{a}-T_{v}\right)
$$

where, $\rho_{t} . c_{t} . k_{t}$ and $T_{t}$ represent density $\left(\mathrm{kg} \mathrm{m}^{-3}\right)$, heat capacity $\left(\mathrm{j} \mathrm{kg}^{-1} \mathrm{~K}^{-1}\right)$, thermal conductivity $\left(\mathrm{W} \mathrm{m} \mathrm{m}^{-}\right.$ $\left.{ }^{1} \mathrm{~K}^{-1}\right)$ and temperature $(\mathrm{K})$ of the tissue, respectively. $\rho_{b}$ and $c_{b}$ are density and heat capacity values of the blood. $q_{m e t}$ is metabolic heat generation rate $\left(\mathrm{W} \mathrm{m}^{-3}\right) . \omega$ is blood perfusion rate $\left(\mathrm{s}^{-1}\right) . T_{a}$ is the deepbody arterial temperature $(\mathrm{K})$ and $T_{v}$ is the venous (the skin temperature) temperature $(\mathrm{K})$. In this paper, $T_{a}$ was assumed as constant at $310 \mathrm{~K}$ (Chen and Wright, 2012). In addition, it is assumed that the rate of metabolic heat production is only in muscle tissue. Since the thermal conductivity of fat tissue is lower, the temperature gradient is higher under steady state condition. Therefore, in this study TEG module was implanted in fat tissue.

Convective heat flux on skin surface can be calculated by applying Newton's law of cooling (Wijethunge et al., 2018).

$$
q_{c}^{\prime \prime}=h_{s_{\text {kin }}}\left(T_{\text {skin }}-T_{\text {air }}\right)
$$

where, $T_{\text {skin }}$ and $T_{\text {air }}$ are the upper skin temperature $(\mathrm{K})$ and air temperature $(\mathrm{K})$, respectively. The air temperature was chosen as $295 \mathrm{~K}$.

Table 3. Convective heat transfer coefficient of skin (Chen and Wright, 2012)

\begin{tabular}{ccc}
\hline Condition & Equation & Velocity (m s $\left.\mathbf{~ s}^{\mathbf{1}}\right)$ \\
\hline Seated & $\mathrm{h}_{\text {skin }}=8.3 v^{0.6}$ & v=air velocity \\
Waking or Running & $\mathrm{h}_{\text {skin }}=8.6 v^{0.56}$ & v=moving velocity \\
\hline
\end{tabular}

The convection heat transfer coefficient used in the heat model is shown in Table 3 (Chen and Wright, 2012). $h_{\text {skin }}\left(\mathrm{W} \mathrm{m}^{-2} \mathrm{~K}^{-1}\right)$ is calculated differently while seated and in moving. The radiative heat flux on the skin is given as follows,

$$
q_{r}^{\prime \prime}=\varepsilon \sigma\left(T_{\text {air }}^{4}-T_{\text {skin }}^{4}\right)
$$

where, $\sigma\left(\mathrm{W} \mathrm{m}^{-2} \mathrm{~K}^{-4}\right)$ is Stephan Boltzmann constant and $\varepsilon$ is skin emissivity and it is regarded as being 0.94 (Wijethunge et al., 2018). Heat loss by evaporation from skin is given by equations (4-7). $q_{e}$ indicates the evaporating heat loss $\left(\mathrm{W} \mathrm{m}^{-2}\right)$ caused by sweat secretion. It consists of the sum of implicit sweat secretion $q_{d i f}\left(\mathrm{~W} \mathrm{~m}^{-2}\right)$ and explicit sweat secretion $q_{r s w}\left(\mathrm{~W} \mathrm{~m}^{-2}\right)$.

$$
\begin{aligned}
& q_{e}^{\prime \prime}=q_{d i f}^{\prime \prime}+q_{r s w}^{\prime \prime} \\
& q_{d i f}^{\prime \prime}=3.054\left(0.256 T_{\text {skin }}-3.37-p_{a}\right) \\
& q_{r s w}^{\prime \prime}=16.7 h_{\text {skin }} W_{r s w}\left(0.256 T_{\text {skin }}-3.37-p_{a}\right) \\
& p_{a}=\phi_{a} p_{a}^{*}
\end{aligned}
$$

where, $\mathrm{W}_{\mathrm{rsw}}$ is skin humidity, $p_{a}(\mathrm{kPa})$ is vapor pressure in ambient air, $p_{a}{ }^{*}(\mathrm{kPa})$ is saturated vapor pressure at surrounding air temperature and $\phi_{a}$ is relative humidity of surrounding.

\section{Thermoelectric model}

TEGs are devices that convert heat energy resulting from temperature difference into electrical energy (Siddique et al., 2017). These devices usually contain that thermoelement materials consisting of $\mathrm{p}$ and $\mathrm{n}$ semiconductors, the binding material that connects them and ceramic materials that hold the module together (Soleimani et al., 2020). $\mathrm{Bi}_{2} \mathrm{Te}_{3}$ and $\mathrm{Sb}_{2} \mathrm{Te}_{3}$ materials are generally used for 
thermoelements which have high Seebeck coefficient and low electrical resistance. In this study, materials were chosen $\mathrm{Bi}_{2} \mathrm{Te}_{3}$ and $\mathrm{Sb}_{2} \mathrm{Te}_{3}$ for n-type and p-type semiconductors, copper as connecting and $\mathrm{Al}_{2} \mathrm{O}_{3}$ as substrate. These thermocouples are connected in series with each other and thermally in parallel by the top and bottom copper layers (Soleimani et al., 2020), (Nguyen Huu et al., 2018). Air is used as filling material. Properties of TEG materials are summarized in Table 4 (Soleimani et al., 2020), (Wang et al., 2013).

In this table, $c_{p}$ is specific heat capacity $\left(\mathrm{j} \mathrm{kg}^{-1} \mathrm{~K}^{-1}\right), k$ is thermal conductivity $\left(\mathrm{W} \mathrm{m}^{-1} \mathrm{~K}^{-1}\right), \rho$ is density $\left(\mathrm{kg} \mathrm{m}^{-3}\right), \alpha$ is Seebeck Coefficient $\left(\mathrm{V} \mathrm{K}^{-1}\right), r_{e}$ is electrical resistivity $(\Omega \mathrm{m}), \sigma$ is electrical conductivity $\left(\mathrm{S} \mathrm{m}^{-1}\right), A$ is cross-sectional area and $L_{\text {leg }}$ is thermocouple leg length $(\mathrm{m})$. In this paper, 144 rectangular shaped p-type and n-type thermoelectric legs were used. Leg dimension is $1.6 \mathrm{~mm}$ (and $3.2 \mathrm{~mm}$ ) height, $1.4 \mathrm{~mm}$ width and $1.4 \mathrm{~mm}$ depth. The thicknesses of TEG electrodes and substrate are $0.1 \mathrm{~mm}$ and $1 \mathrm{~mm}$ respectively, and the TEG size is $30 \mathrm{~mm} \times 30 \mathrm{~mm} \times 3.8 \mathrm{~mm}$ (Nguyen Huu et al., 2018).

Table 4. Properties of TEG materials (Nguyen Huu et al., 2018). *(Soleimani et al., 2020) ** (Wang et al., 2013)

\begin{tabular}{ccccc}
\hline & $\mathbf{B i}_{\mathbf{2}} \mathbf{T e}_{\mathbf{3}}$ & $\mathbf{S b}_{\mathbf{2}} \mathbf{T e}_{\mathbf{3}}$ & $\mathbf{C u}$ & $\mathbf{A l}_{\mathbf{2}} \mathbf{O}_{\mathbf{3}}$ \\
\hline$c_{p}$ & 198 & 214 & $385 *$ & $730 *$ \\
$k$ & 1.6 & 1.6 & $400 *$ & $35 *$ \\
$\rho$ & 7670 & 6440 & $8960 *$ & $3965 * *$ \\
$\alpha$ & $-2.1 \times 10^{-4 *}$ & $1.89 \times 10^{-4}$ & - & - \\
$r_{e}$ & $15 \times 10^{-6}$ & $25 \times 10^{-6}$ & $1.6 \times 10^{-8} * *$ & - \\
$\sigma$ & $1.08 \times 10^{6 *}$ & $1.27 \times 10^{6 *}$ & $5.99 \times 10^{7} *$ & - \\
$L_{l e g}$ & $1.96 \times 10^{6}$ & $1.96 \times 10^{6}$ & $1.4 \times 10^{7}$ & - \\
\hline
\end{tabular}

The energy obtained from the temperature difference between the thermocouple legs is due to the Seebeck effect. For this reason the output voltage varies depending on the temperatures difference (C. Yuan et al., 2020). The following equations are used to calculate the output power (Jaziri et al., 2020). Formula of the output voltage $(\mathrm{V})$ is given as,

$$
V_{\text {out }}=N \alpha_{p-n} \Delta T
$$

where, $N$ is number of thermocouple pairs, $\alpha_{p-n}\left(\mathrm{~V} \mathrm{~K}^{-1}\right)$ is difference of Seebeck coefficients of $p-n$ semiconductors and the $\Delta \mathrm{T}(\mathrm{K})$ is temperature difference between the TEG legs.

Another parameter affecting the output power is the internal resistance $(\Omega)$ and its formula follows as,

$$
R_{T E G}=N\left(\frac{r_{e_{p}} L_{p}}{A_{p}}+\frac{r_{e_{n}} L_{n}}{A_{n}}+2 \frac{r_{e C} L_{C}}{A_{c}}\right)
$$

where $r_{e}, L$ and $A$ are respectively thermoelements and contacts electrical resistivities $(\Omega \mathrm{m})$, lengths (m) and cross-sectional areas $\left(\mathrm{m}^{2}\right)$. Subscripts $p, n$ and $c$ represent $p$-type semiconductor, $n$-type semiconductor and the copper. The power output of TEG calculated with Equation 10.

$$
P=V_{\text {out }}^{2} \frac{R_{L}}{\left(R_{T E G}+R_{L}\right)^{2}}
$$

$R_{L}(\Omega)$ is external load and when $R_{L}$ has the same value with $R_{T E G}$, the maximum power $(\mathrm{W})$ is calculated as Equation 11.

$$
P_{\max }=\frac{V_{\text {out }}^{2}}{4 R_{T E G}}
$$

\section{Boundary condition and mesh model}

All numerical model computations were performed using ANSYS software. In the numerical model, the symmetry boundary condition was used for two surfaces to save computation time. Convection boundary condition was applied on the skin surface. The temperature boundary condition $\left(\mathrm{T}_{\mathrm{a}}=310 \mathrm{~K}\right)$ was given to the lower surface of the muscle tissue. In addition, a volumetric heat source was given to the muscle tissue $\left(420 \mathrm{~W} \mathrm{~m}^{-3}-20.000 \mathrm{~W} \mathrm{~m}^{-3}\right)$. 
Energy equation was discretized by using the finite volume method (FVM). A range of $496.774-$ 750.314 number of elements were used in the muscle, fat, skin and TEG domains. Hexahedral grid structure was used for muscle, skin and TEG legs, and tetrahedral grid structure was used for fat tissue and other TEG components. The mesh structure of the numerical model is shown in Figure 2.
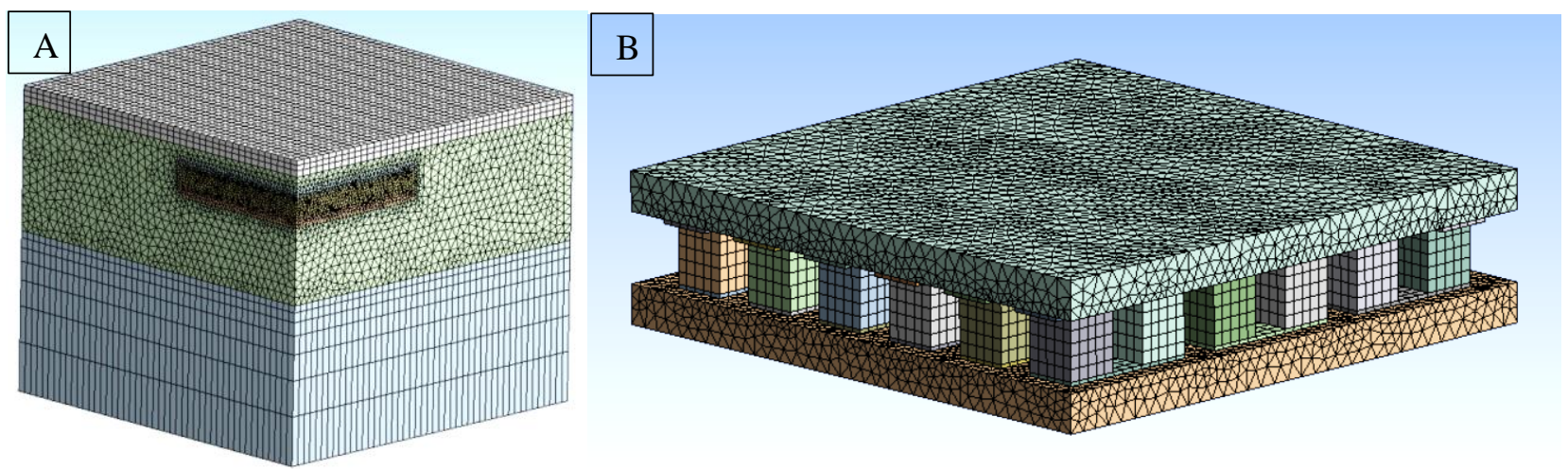

Figure 2. A) Mesh structure of living tissues and TEG domains. B) Mesh structure TEG domains (except filling domain).

Figure 3 shows the mesh structure of the TEG domain, omitting the filling domain. The mesh structure on the legs is separated into five portions to see the temperature distribution properly.

\section{$\mathbf{2}^{\mathrm{K}}$ Factorial Design}

Generally, factorial designs are represented in the form of $S^{k}, S$ and $k$ indicate that number of level and $\mathrm{k}$ number of factors, respectively (Ryan, 2007).

The $2^{\mathrm{k}}$ factorial design is particularly useful in the early stages of experimental study. It allows the investigation of many factors that affect the response of the experiment. Because in a complete factorial design, $2^{\mathrm{k}}$ design provides the least number of runs. Since there are two levels for each factor, the response is assumed to be approximately linear over the range of factor levels. Although the assumption of linearity in factor effects in $2 \mathrm{k}$ design is a potential concern, they linearity need not be perfect. If interaction terms are added to the first order regression model, the equation can be written as follow,

$$
y=\beta_{0}+\sum_{i=1}^{k} \beta_{i} x_{i}+\sum_{i<} \sum_{j} \beta_{i j} x_{i} x_{j}+\epsilon
$$

where, $y$ indicates response, $\beta$ is regression model coefficients, $x$ coded variable and $\in$ is random error (Montgomery, 2013).

Data transformations are an effective way of dealing with non-normal responses and related variance inequality problems. Box - Cox method can be used to choose the transformation form effectively. Log transformation is one of these transformations and is given as (Montgomery, 2013),

$$
y^{*}=\ln (y)
$$

\section{RESULT AND DISCUSSION}

In the study, the effect of four important factors on temperature difference of TEG legs and on power output of TEG was investigated with using the unreplicated $2^{5}$ design method. Factor and level data are shown in Table 5. Fat thickness, $L_{f a t}$, was selected as $12 \mathrm{~mm}$ and $30 \mathrm{~mm}$. Heat generation, $Q_{g e n}$, has been considered to occur only in muscle tissue. In order to examine the change in TEG power generation of heat transfer through the skin, a convection boundary condition was applied to the skin surface $\left(h_{\text {skin }}=10 \mathrm{~W} \mathrm{~m}^{-2} \mathrm{~K}^{-1}-80 \mathrm{~W} \mathrm{~m}^{-2} \mathrm{~K}^{-1}\right)$. Only leg length, $L_{\text {leg, }}$, was changed for the same TEG parameters. 
Table 5. Skin and TEG factors

\begin{tabular}{cccc}
\hline Factors & Parameters & Low (-1) & High (+1) \\
\hline A & $L_{f a t}$ & $12 \mathrm{~mm}$ & $30 \mathrm{~mm}$ \\
B & $L_{\text {leg }}$ & $3.8 \mathrm{~mm}$ & $7 \mathrm{~mm}^{-1}$ \\
C & $h_{\text {skin }}$ & $10 \mathrm{~W} \mathrm{~m}^{-2} \mathrm{~K}^{-1}$ & $80 \mathrm{~W} \mathrm{~m}^{-2} \mathrm{~K}^{-1}$ \\
D & $Q_{g e n}$ & $420 \mathrm{~W} \mathrm{~m}^{-3}$ & $20000 \mathrm{~W} \mathrm{~m} \mathrm{~W}^{-3}$ \\
\hline
\end{tabular}

As an additional information, the place of TEG in fat tissue is not included as a factor. Because, it is assumed that there is no heat generation in the fat tissue and the thermal conductivity of tissues are not temperature dependent. Thus, the temperature gradient of fat tissue is constant. Steady state heat conduction equation in fat tissue is given as (Çengel and Ghajar, 2015),

$$
\frac{d^{2} T}{d x^{2}}=0
$$

In fat tissue, the temperature distribution will be linear. Therefore, the temperature difference between the $p$ and $n$ legs of TEG does not change in any part of the fat tissue.

The numerical computation pattern of the $2^{4}$ factorial design is given in Table 6 . This table includes 4 factors and their combinations. Besides, result of this combination, there are 2 response output (Table 6). The maximum and minimum value of the temperature difference $(\Delta \mathrm{T})$ between legs are $0.26{ }^{\circ} \mathrm{C}$ and $1.13{ }^{\circ} \mathrm{C}$, respectively. The maximum value of temperature difference occurs with high factors $\mathrm{B}, \mathrm{C}, \mathrm{D}$ and low A factor. Maximum and minimum values for TEG power output $\left(P_{\max }\right)$ are $3.86 \mu \mathrm{W}$ and 55.54 $\mu \mathrm{W}$, respectively. In addition, the temperature on the skin varies between $298.67 \mathrm{~K}$ and $305.57 \mathrm{~K}$. It is obvious that the increase in fat thickness negatively affects to the $\Delta \mathrm{T}$ and $\mathrm{P}_{\max }$. These results support the study in reference (Yang and Liu, 2010). However, whether there is an interaction between the factors and the effects of these factors on the responses are evaluated in detail with the analysis of variance (ANOVA) model.

Table 6. Numerical computation plan and corresponding results of 24 factorial design

\begin{tabular}{|c|c|c|c|c|c|c|}
\hline \multirow[b]{2}{*}{ Run } & \multicolumn{4}{|c|}{ Factors } & \multicolumn{2}{|c|}{ Responses } \\
\hline & $\mathbf{A}$ & B & C & D & $\Delta \mathrm{T}\left({ }^{\circ} \mathrm{C}\right)$ & $P_{\max }(\mu W)$ \\
\hline 1 & 12 & 1.6 & 4.03 & 420 & 0.31 & 8.35 \\
\hline 2 & 30 & 1.6 & 4.03 & 420 & 0.21 & 3.86 \\
\hline 3 & 12 & 3.2 & 4.03 & 420 & 0.62 & 16.81 \\
\hline 4 & 30 & 3.2 & 4.03 & 420 & 0.44 & 8.56 \\
\hline 5 & 12 & 1.6 & 12.42 & 420 & 0.42 & 15.13 \\
\hline 6 & 30 & 1.6 & 12.42 & 420 & 0.26 & 5.84 \\
\hline 7 & 12 & 3.2 & 12.42 & 420 & 0.86 & 32.38 \\
\hline 8 & 30 & 3.2 & 12.42 & 420 & 0.53 & 12.22 \\
\hline 9 & 12 & 1.6 & 4.03 & 20000 & 0.39 & 13.22 \\
\hline 10 & 30 & 1.6 & 4.03 & 20000 & 0.28 & 6.61 \\
\hline 11 & 12 & 3.2 & 4.03 & 20000 & 0.83 & 29.85 \\
\hline 12 & 30 & 3.2 & 4.03 & 20000 & 0.57 & 13.98 \\
\hline 13 & 12 & 1.6 & 12.42 & 20000 & 0.55 & 24.85 \\
\hline 14 & 30 & 1.6 & 12.42 & 20000 & 0.34 & 9.79 \\
\hline 15 & 12 & 3.2 & 12.42 & 20000 & 1.13 & 55.44 \\
\hline 16 & 30 & 3.2 & 12.42 & 20000 & 0.69 & 20.5 \\
\hline
\end{tabular}

The temperature distribution over the tissue is shown in Figure $3 \mathrm{~A}$. The temperature begins from $37{ }^{\circ} \mathrm{C}$ on the lower surface of the muscle tissue and dropped to $29.9{ }^{\circ} \mathrm{C}$ on the skin. 
Figure 3. A) Main effects plots for mean response (symmetric model) B) Main effects plots for mean response (symmetric model).

Figure $3 \mathrm{~B}$ shows the temperature distribution over the TEG. While the average temperature on the lower leg surface is $31.17^{\circ} \mathrm{C}$, the average temperature on the upper surface is $31.48{ }^{\circ} \mathrm{C}$.

\section{ANOVA Results and Regression Model}

Analysis of variance (ANOVA) statistical models is used to examine the effects of factors on the responses in more detail. As responses, the temperature difference $\triangle \mathrm{T}$ between legs and TEG max power output are selected. ANOVA calculations were carried out using the codes of the open source RStudio software. According to the Box-Cox method suggestion, calculations were performed using natural log transformation. Table 7 shows the ANOVA model of main effects and two-way interactions for $\Delta \mathrm{T}$.

Table 7. ANOVA model for $\Delta \mathrm{T}$

\begin{tabular}{cccccc}
\hline Term & DF & $\boldsymbol{S S}$ & $\boldsymbol{M S}$ & $\boldsymbol{F}$ & $\boldsymbol{P}$-value \\
\hline A & 1 & 0.71 & 0.71 & 3301.7 & $<0.0001^{*}$ \\
B & 1 & 2.09 & 2.09 & 9682.2 & $<0.0001^{*}$ \\
C & 1 & 0.26 & 0.26 & 1184.8 & $<0.0001^{*}$ \\
D & 1 & 0.26622 & 0.27 & 1234.2 & $<0.0001^{*}$ \\
AB & 1 & 0.00005 & 0.00005 & 0.2107 & 0.665 \\
AC & 1 & 0.014 & 0.014 & 66.2 & $0.00046^{*}$ \\
AD & 1 & 0 & 0 & 0.0028 & 0.96 \\
BC & 1 & 0.0002 & 0.0002 & 0.022 & 0.89 \\
BD & 1 & 0 & 0 & 0.91 & 0.38 \\
CD & 1 & 0.00108 & 0.00022 & 0.0046 & 0.95 \\
Residuals & 5 & & & \\
\hline
\end{tabular}

* indicates significant

where, $D F$ is Degree of freedom, $S S$ is sum of square, $M S$ is mean square, $F$ is $\mathrm{F}$ ratio and $P$-value is probability. The $P$-value is used to determine whether the main effects and interaction effects are significant. If P-value less than 0.05, the model parameters considered as significant (Yurata et al., 2020). Table 8 shows the ANOVA model of main effects and interaction effects of the $P_{\max }$.

Table 8. ANOVA model for Pmax

\begin{tabular}{cccccc}
\hline Term & Df & Sum $\boldsymbol{S q}$ & Mean Sq & $\boldsymbol{F}$ & $\boldsymbol{P}$-value \\
\hline A & 1 & 31079,00 & 30713,00 & 3301.7 & $<0.0001^{*}$ \\
B & 1 & 12086,00 & 12086,00 & 2696.2 & $<0.0001^{*}$ \\
C & 1 & 44228,00 & 44228,00 & 1184.8 & $<0.0001^{*}$ \\
D & 1 & 44348,00 & 44348,00 & 1234.2 & $<0.0001^{*}$ \\
AB & 1 & 0.00018 & 0.00018 & 0.2107 & 0.67 \\
AC & 1 & 0.057 & 0.057 & 661951,00 & $0.00046^{*}$ \\
AD & 1 & 0,00 & 0,00 & 0.0028 & 0.96 \\
BC & 1 & 0.00002 & 0.00002 & 0.022 & 0.89 \\
BD & 1 & 0.00079 & 0.00079 & 0.9142 & 0.38 \\
CD & 1 & 0,00 & 0,00 & 0.0046 & 0.95 \\
Residuals & 5 & 0.00431 & 0.00086 & & \\
\hline
\end{tabular}

* indicates significant 
As a result of ANOVA models, Main effects (A, B, C and D) and AC interaction effects are significant on $\Delta \mathrm{T}$ and $P_{\max }$ responses. The main effect plot shown in Figure 6 is an efficient method of visualizing the effect size. The difference in mean response between two levels of a factor is the main effect. While B, C and D main effects have a positive effect on $\Delta \mathrm{T}$, A has a negative effect (Ghotbi Ravandi et al., 2016).

The contribution of each term on the response is determined by the percentage contribution. It measures percentage contribution of each model term to the total sum of squares. The percentage contribution provides an overview of the relative importance of each model term (Montgomery, 2013). Contribution percentage of each model term is given in Table 9.
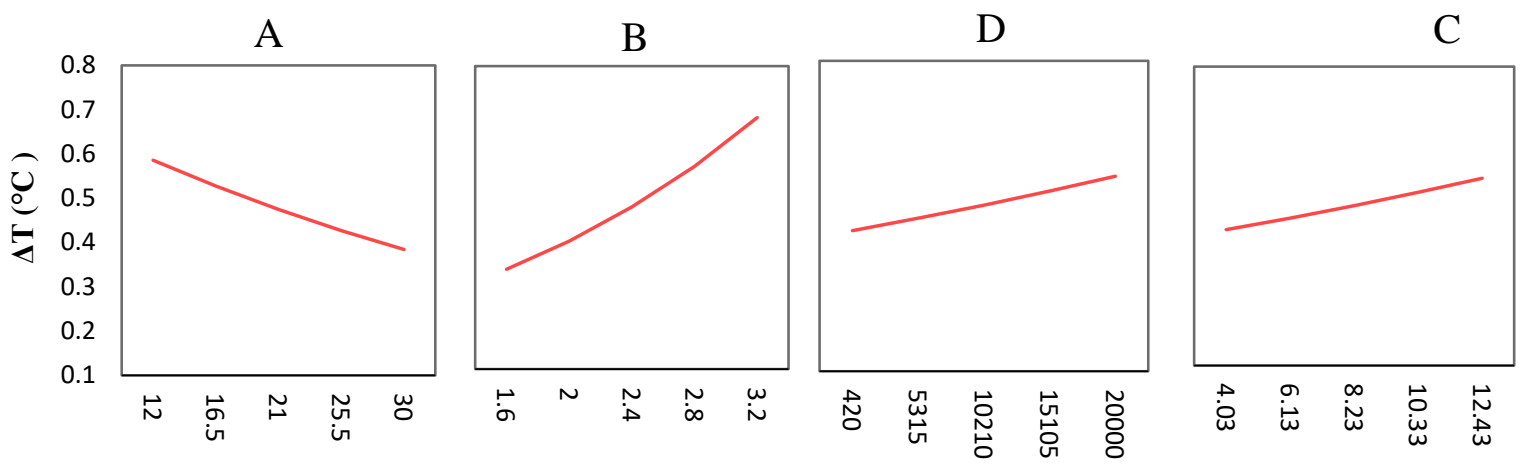

Figure 4. Main effects plots for mean response

Table 9. Percentage contribution of each term

\begin{tabular}{cccccc}
\hline Term & DF & SS & MS & $\boldsymbol{F}$ & $\boldsymbol{P}$-value \\
\hline A & 1 & 0.71 & 0.71 & 3301.7 & $<0.0001^{*}$ \\
B & 1 & 2.09 & 2.09 & 9682.2 & $<0.0001^{*}$ \\
C & 1 & 0.26 & 0.26 & 1184.8 & $<0.0001^{*}$ \\
D & 1 & 0.26622 & 0.27 & 1234.2 & $<0.0001^{*}$ \\
AB & 1 & 0.00005 & 0.00005 & 0.2107 & 0.665 \\
AC & 1 & 0.014 & 0.014 & 66.2 & $0.00046^{*}$ \\
AD & 1 & 0 & 0 & 0.0028 & 0.96 \\
BC & 1 & 0 & 0.0002 & 0.022 & 0.89 \\
BD & 1 & 0.0002 & 0 & 0.91 & 0.38 \\
CD & 1 & 0 & 0.00022 & 0.0046 & 0.95 \\
Residuals & 5 & 0.00108 & & \\
\hline
\end{tabular}

Factors $\mathrm{A}$ and $\mathrm{B}$ have dominant effects on responses $\left(\Delta \mathrm{T}\right.$ and $\left.P_{\max }\right)$ as their Contribution percentage are higher than other factors. While the percentage contribution of the factor $\mathrm{B}$ on $\Delta \mathrm{T}$ response is $62.59 \%$, this value decreased to $31.79 \%$ on the $P_{\max }$. The reason of this, as leg length of TEG increases, the internal resistance $R_{T E G}$ also increases.

The two-way interaction $\mathrm{AC}$ has a small effect on both responses as contribution percentages are $0.43 \%$ and $0.78 \%$.

The regression model for main factors and one significant interaction effects is expressed as,

$\ln y=\beta_{0}+\beta_{1} A+\beta_{2} B+\beta_{3} C+\beta_{4} D+\beta_{5} A C$

Table 10 shows the values of the constants $(\beta)$ of the regression model, $y$ represent response and $\mathrm{R}^{2}$ is defined as the proportion of the variability in the data "explained" by the ANOVA. $\mathrm{R}^{2}$ ranges from 0 to 1 and it is desirable that the $\mathrm{R}^{2}$ value be close to the value 1 (Montgomery, 2013). 
Table 10. The regression model constants

\begin{tabular}{ccc}
\hline Term & $\boldsymbol{\Delta T}$ & $\boldsymbol{P m a x}$ \\
\hline$\beta_{0}$ & $-1.86 \mathrm{E}+00$ & $1.42 \mathrm{E}+00$ \\
$\beta_{1}$ & $-1.69 \mathrm{E}-02$ & $-3.39 \mathrm{E}-02$ \\
$\beta_{2}$ & $4.52 \mathrm{E}-01$ & $4.77 \mathrm{E}-01$ \\
$\beta_{3}$ & $4.67 \mathrm{E}-02$ & $9.35 \mathrm{E}-02$ \\
$\beta_{4}$ & $1.32 \mathrm{E}-05$ & $2.64 \mathrm{E}-05$ \\
$\beta_{5}$ & $-7.91 \mathrm{E}-04$ & $-1.58 \mathrm{E}-03$ \\
$\mathrm{R}^{2}$ & 0.9994 & 0.9989 \\
\hline
\end{tabular}

\section{CONCLUSION}

In the study, a thermal model of human living tissue was investigated to determine parameters affecting temperature difference of TEG legs and power output (responses). In order to carry out a more realistic analysis, all components of the TEG have been added to the model. In addition, statistical models were used to better evaluate the output data. Four important factors were selected and their effects on responses were analysed statistically using $2^{\mathrm{k}}$ factorial design and ANOVA.

Maximum and minimum values are $0.26{ }^{\circ} \mathrm{C}$ and $1.13{ }^{\circ} \mathrm{C}$ respectively for the temperature difference, $\Delta \mathrm{T}$, between legs. These values are $3.86 \mu \mathrm{W}$ and $55.54 \mu \mathrm{W}$ for TEG max power output $\left(\mathrm{P}_{\max }\right)$, respectively. As a result of ANOVA, main effects (A, B, C and D) and AC two-way interaction effects are statistically significant $(\mathrm{P}$-value $<0.05)$. The effects of $\mathrm{B}, \mathrm{C}, \mathrm{D}$ factors on $\Delta \mathrm{T}$ and $\mathrm{P}_{\max }$ are positive. That is, the increase of these factors is provided to increase the $\Delta \mathrm{T}$ and $\mathrm{P}_{\max }$ values. However, increasing the A factor has a negative effect on both responses.

Since, the percentage contribution of the A and B factors is high, they have strong effects on both responses. However, although the AC interaction effect is statistically significant, its effect on the response is very low (Table 9).

As a result, the amount of power generated by TEG implanted in human tissue is computed to be low (Table 6). However, these conclusions are based on numerical analysis under certain situations and not be exact. It will be beneficial to compare the acquired findings to the experimental data. TEG materials, on the other hand, are not yet biocompatible. However, in future investigations, the experimental procedure may be conducted on a portion of animal tissue that is closest to human tissue using standard TEG.

Designing TEGs are suitable for human tissue and increasing its efficiency by using more convenient materials will increase the TEG power output. Thus, it will be possible to meet the power requirements of biomedical devices implanted in the human body with implanted TEGs.

\section{Conflict of Interest}

The article authors declare that there is no conflict of interest between them.

\section{Author's Contributions}

The authors declare that they have contributed equally to the article.

\section{REFERENCES}

Chakraborty A, Saha BB, Koyama S, Ng KC, 2006. Thermodynamic modelling of a solid state thermoelectric cooling device: Temperature-entropy analysis. International Journal of Heat and Mass Transfer, 49(19-20): 3547-3554.

Chen A, Wright P, 2012. Chapter 26: Medical Applications of Thermoelectrics, Modules, Systems, and Applications in Thermoelectrics, pp. 1-22, CRC Press, Florida - United States.

Çengel YA, Ghajar AJ, 2015. Heat and mass transfer: Fundamentals \& Applications (Fifth edition). McGraw Hill Education, United States. 
Ghotbi Ravandi E, Rahmannejad R, Karimi-Nasab S, Sarrafi A, 2016. Sensitivity analysis of effective parameters on water curtain performance for crude oil storage in Iranian URC using the $2 \mathrm{k}$ factorial design and numerical modeling. Tunnelling and Underground Space Technology, 58: 247-256.

Hoffmann K, Stuucker M, Dirschka T, Goortz S, El-Gammal S, Dirting K, Hoffmann A, Altmeyer P, 1994. Twenty MHz Bscan sonography for visualization and skin thickness measurement of human skin. Journal of the European Academy of Dermatology and Venereology, 3(3): 302-313.

Ishida Y, Carroll JF, Pollock ML, Graves JE, Leggett SH, 1992. Reliability of B-mode ultrasound for the measurement of body fat and muscle thickness. American Journal of Human Biology, 4(4): 511-520.

Jaziri N, Boughamoura A, Müller J, Mezghani B, Tounsi F, Ismail M, 2020. A comprehensive review of Thermoelectric Generators: Technologies and common applications. Energy Reports, 6(7): 264-287.

Liu KC, Chen YS, Chen MK, 2016. Test for Thermoelectric Self Cooling. The International Conference on Computing and Precision Engineering (ICCPE 2015), August 02, 2016, 71: 05006.

Montgomery DC, 2013. Design and analysis of experiments (Eighth edition). John Wiley \& Sons, Inc. New Jersey, United States.

Nguyen Huu T, Nguyen Van T, Takahito O, 2018. Flexible thermoelectric power generator with Y-type structure using electrochemical deposition process. Applied Energy, 210: 467-476.

Rosli N, Mohamed H, 2018. Experimental Study on the Use of Thermoelectric Generators in Harvesting Human Body Heat. International Journal of Engineering \& Technology, 7(4.35): 264-269.

Ryan TP, 2007. Modern Experimental Design. John Wiley \& Sons, Inc. New Jersey, United States.

Schmidt CL, Skarstad PM, 2001. The future of lithium and lithium-ion batteries in implantable medical devices, Journal of Power Sources, 97-98: 742-746,

Şener M, Arslan FM, Gürses BO, Gürlek G, 2021. Experimental Investigation of Thermoelectric Self-Cooling System for the Cooling of Ultrasonic Transducer Drivers. Journal of Polytechnic, 1-1.

Siddique ARM, Mahmud S, Heyst BV, 2017. A review of the state of the science on wearable thermoelectric power generators (TEGs) and their existing challenges. Renewable and Sustainable Energy Reviews, 73: 730-744.

Soleimani Z, Zoras S, Cui Y, Ceranic B, Shahzad S, 2020. Design of heat sinks for wearable thermoelectric generators to power personal heating garments: A numerical study. IOP Conference Series: Earth and Environmental Science, Sustainability in the built environment for climate change mitigation: SBE19 Thessaloniki, October 23-25, 2019, Thessaloniki, Greece, 410: 012096.

Wang W, Cionca V, Wang N, Hayes M, O’Flynn B, O’Mathuna C, 2013. Thermoelectric Energy Harvesting for Building Energy Management Wireless Sensor Networks. International Journal of Distributed Sensor Networks, 9(6):1-14.

Wijethunge D, Kim D, Kim W, 2018. Simplified human thermoregulatory model for designing wearable thermoelectric devices. Journal of Physics D: Applied Physics, 51(5): 055401.

Yang Y, Liu J, 2010. Evaluation of the power-generation capacity of wearable thermoelectric power generator. Frontiers of Energy and Power Engineering in China, 4(3): 346-357.

Yang Y, Wei XJ, Liu J, 2007. Suitability of a thermoelectric power generator for implantable medical electronic devices. Journal of Physics D: Applied Physics - IOPscience, 40(18): 5790-5800.

Yuan CD, Jadhav OS, Rudnyi EB, Hohlfeld D, Bechtold T, 2018. Parametric model order reduction of a thermoelectric generator for electrically active implants. 19th International Conference on Thermal, Mechanical and Multi-Physics Simulation and Experiments in Microelectronics and Microsystems (EuroSimE),France, April 15-18, 2018, pp:1-6.

Yuan C, Kreß S, Sadashivaiah G, Rudnyi E B, Hohlfeld D, Bechtold T, 2020. Towards efficient design optimization of a miniaturized thermoelectric generator for electrically active implants via model order reduction and submodeling technique. International Journal for Numerical Methods in Biomedical Engineering, 36(4):1-16.

Yurata T, Piumsomboon P, Chalermsinsuwan B, 2020. Effect of contact force modeling parameters on the system hydrodynamics of spouted bed using CFD-DEM simulation and 2 factorial experimental design. Chemical Engineering Research and Design, 153: 401-418. 